\title{
Suitable conditions for natural regeneration in variable retention harvesting of southern Patagonian Nothofagus pumilio forests
}

\author{
Mónica D.R. Toro Manríquez ${ }^{1 *}$ (D), Juan M. Cellini², María V. Lencinas ${ }^{1}$, Pablo L. Peri ${ }^{3}$, Karen A. Peña Rojas ${ }^{4}$ and \\ Guillermo J. Martínez Pastur ${ }^{1}$
}

\begin{abstract}
Background: Variable retention (aggregated and dispersed retention) harvesting proposed for Nothofagus pumilio was designed for timber purposes and biodiversity conservation. Harvesting by opening canopy generates different microenvironments and creates contrasting conditions for seedling establishment, growth, and eco-physiology performance due to synergies (positives or negatives) with biotic and abiotic factors. This study evaluated the regeneration in different microenvironment conditions within managed stands during 5 years after harvesting. Remnant forest structure after harvesting and different microenvironments were characterized in managed stands, where 105 regeneration plots were measured ( 3 stands $\times 7$ microenvironments $\times 5$ replicas). We characterized the seedling bank, as well as growth and ecophysiology performance of the regeneration. Univariate and multivariate analyses were conducted for the comparisons.
\end{abstract}

Results: Microenvironments offered different environmental conditions for natural regeneration (soil moisture and light availability). Seedling under debris and dicot plants showed better eco-physiological performance, establishment, and growth than plants growing under monocots or located in the dispersed retention without the protection of other understory plants. The most unfavorable microenvironment conditions were high canopy cover of remnant trees (inside the aggregates or close to trees in the dispersed retention) and heavily impacted areas (skidder extraction roads).

Conclusions: Favorable microenvironments in the harvested areas will improve the natural recruitment, growth, and eco-physiology performance of the natural regeneration after harvesting. It is necessary to develop new silvicultural practices that decrease the unfavorable microenvironments (e.g., road density or excessive woody accumulation), to assure the success of the proposed silvicultural method.

Keywords: Aggregated retention, Dispersed retention, Microenvironments, Environmental variables, Biometric values, Biomass allocation, Eco-physiology

\section{Introduction}

Harvesting of Nothofagus forests in southern Patagonia is mainly based on canopy opening to enhance recruitment and seedlings growth by modifying light, soil moisture (Caldentey et al. 2009; Martínez Pastur et al. 2009, 2011a; Torres et al. 2015), and nutrient availability (Burgess and Wetzel 2000; Catovsky and Bazzaz 2002).

\footnotetext{
* Correspondence: monicatm@cadic-conicet.gob.ar

${ }^{1}$ Centro Austral de Investigaciones Científicas (CADIC), Consejo Nacional de Investigaciones Científicas y Técnicas (CONICET), Houssay 200 (9410), Ushuaia, Tierra del Fuego, Argentina

Full list of author information is available at the end of the article
}

The rationale of the silvicultural practices is based on the natural forest gap dynamics, where seedling establishment, growth, and yield are enhanced (Messier et al. 1999; Caldentey et al. 2009; Promis et al. 2010). In these forests, abundant seedling establishment occurs after harvesting mainly from pre-existing regeneration (Gea et al. 2004).

Canopy opening, both in natural conditions or under human-induced disturbances, changes the availability of indispensable resources and/or create new microsites that allowed the establishment and growth of seedlings 
(Christie and Armesto 2003; Bailey et al. 2012; Valenzuela et al. 2016; Toro Manríquez et al. 2018). Harvesting creates new microenvironments by generating large amounts of woody debris, which can potentially improve the eco-physiological response and the growth of seedlings compared with less shelter conditions (Martínez Pastur et al. 2012, 2014). The canopy opening determines a significant increase of the effective rainfall that reaches to the soil, increasing the moisture levels that can limit the seedling performance (Promis et al. 2010; Martínez Pastur et al. 2011b; Dreiss and Volin 2013). Both factors (moisture and light availability) can explain most of the establishment, growth, and eco-physiological performance of the seedlings (Rey et al. 2004; Lencinas et al. 2007; Martínez Pastur et al. 2007a, 2014; Peri et al. 2009; Soler et al. 2011; Henn et al. 2014). However, negative synergies have been observed in some microenvironments, where large canopy openings can produce drying effects, acting as a limiting factor for regeneration (McIntire et al. 2016; Toro Manríquez et al. 2018), as well as higher radiation levels that can increase the evaporation rates (Martínez Pastur et al. 2011a, 2011b).

Silvicultural practices based on retention systems (e.g., variable retention) maintain legacies of the original forests for multiple objectives (e.g., biodiversity conservation and provision of ecosystem services) (Franklin et al. 1997; Heithecker and Halpern 2007; Martínez Pastur et al. 2009; Luque et al. 2010; Gustafsson et al. 2012; Lindenmayer et al. 2012, 2019; Neyland et al. 2012). Harvesting based on variable retention has been applied in southern Patagonian Nothofagus pumilio (Poepp et. Endl) Krasser forests since 2001, usually as a mix of aggregated and dispersed retention (Martínez Pastur et al. 2000, 2009). In harvested areas through this retention practice, new microenvironments were generated, modifying the microclimate and soil properties (e.g., both by changing the natural cycles of decomposition or by the impact of the skidders) (Martínez Pastur et al. 2014). Dispersed retention between aggregates offered shelter or generate competition with seedlings for soil water and light availability (Martínez Pastur et al. 2011b). These synergies (positive or negatives) depend on debris amount and impacts on over forest soil (Heithecker and Halpern 2007; Bailey et al. 2012; Martínez Pastur et al. 2011b, 2014), the remnant canopy cover (Torres et al. 2015), and the changes produced over understory plants, such as monocots or dicots that can favor or limit the seedling performance (Hörnberg et al. 1997; Kupferschmid and Bugmann 2005; Blood and Titus 2010; Vodde et al. 2010; Martínez Pastur et al. 2012; Toro Manríquez et al. 2018).

Nothofagus pumilio can quickly adjust to the potential changes in the environment (e.g., exposure to high light levels) (Martínez Pastur et al. 2011c). However, mortality after harvesting usually occurred (Martínez Pastur et al. 2013), e.g., recruitment is higher, and mortality is less in shaded areas close to forest edges (Heinemann et al. 2000; Heinemann and Kitzberger 2006; Toro Manríquez et al. 2018). Besides this, other effects that could be modified in these microenvironments are related to the dynamics of the seedling bank, forest biometric variables, allocation of the biomass, and eco-physiological performance (e.g., stomatal conductance was higher in seedlings associated with plants or nurseries than other environments with similar moisture conditions) (Valenzuela et al. 2016). Moreover, seedlings can change its photosynthesis performance under high light levels (Martínez Pastur et al. 2007a). This study aimed to evaluate regeneration in different microenvironment conditions within the managed stands 5 years after harvesting. The tested hypotheses were (1) Harvesting produces different microenvironments that generate positive and negative synergies, mainly related to soil moisture and light availability. (2) Regeneration performance (biometry, biomass allocation, eco-physiology) varied according to the availability of these limiting factors. Moreover, (3) remnant overstory (aggregates and dispersed trees) and roads negatively influence the regeneration, (4) debris acts as shelter for seedlings by decreasing the extreme environmental conditions, and (5) understory can produce positive (nursery plants) or negative (competition) according to the plant type (e.g., dicots or monocots).

\section{Methods}

\section{Study site and climate characterization}

The study site was located in a pure natural Nothofagus pumilio forest on Tierra del Fuego Island (Argentina), harvested using a variable retention method (Martínez Pastur et al. 2009, 2011b). This method kept aggregates (one circular aggregate of $30-\mathrm{m}$ radius per hectare) and dispersed dominant trees $\left(10-15 \mathrm{~m}^{2} \mathrm{ha}^{-1}\right.$ basal area) evenly distributed between the retained aggregates (Martínez Pastur et al. 2007b). The forest was located at Los Cerros Ranch (Fig. 1), and the experiments were established in three stands after 2-4 years harvesting (stand 1 $=2$ years, stand $2=3$ years, and stand $3=4$ years). Stand 1 (15 ha) presented $10 \%$ slope and north aspect, stand 2 (22 ha) presented $15 \%$ slope and northeast aspect, and stand 3 (27 ha) presented 9\% slope and east aspect (Fig. 1).

The stands belong to middle-high site quality and before harvesting had a total over-bark volume of 700$900 \mathrm{~m}^{3} \mathrm{ha}^{-1}$ and a dominant height of $20.5-27.5 \mathrm{~m}$. Climate of the area was characterized by short, cool summers and long, snowy and frozen winters. Only 3 months/year were free of mean daily temperatures under $0{ }^{\circ} \mathrm{C}$, and the growing season was approximately 5 

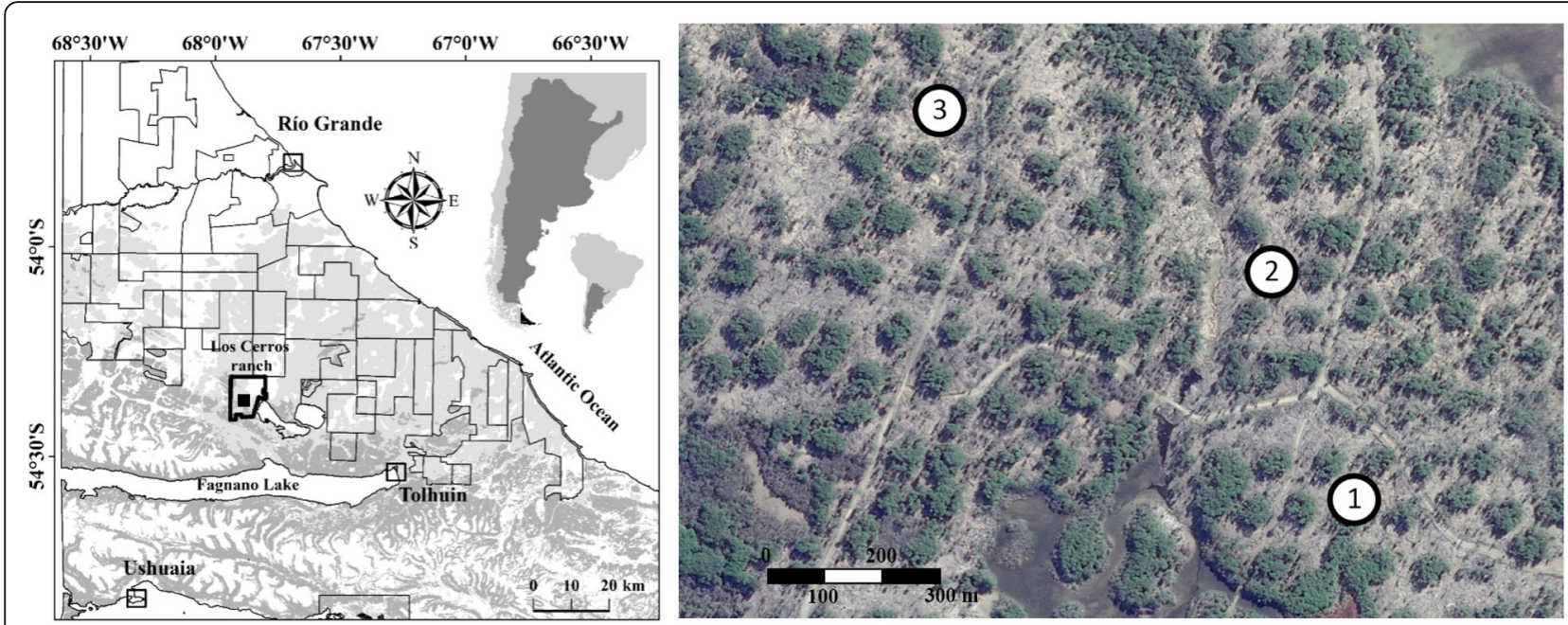

Fig. 1 Location of the study area (right) showing the main cities (squares) and the ranches. In the left, the numbers indicate the studied stands in the harvested area at Los Cerros Ranch

months. Rainfall including snowfall reached up to 600 $\mathrm{mm}$ year $^{-1}$. Annual average wind speed outside forests was $8 \mathrm{~km} \mathrm{~h}^{-1}$, reaching up to $100 \mathrm{~km} \mathrm{~h}^{-1}$ during storms (Martínez Pastur et al. 2009).

\section{Microenvironment stand characterization}

In the studied stands, seven contrasting microenvironments were selected as treatments for the measurements: (1) within the retained aggregates (AR); (2) in the dispersed retention within the influence area of overstory trees $(<2 \mathrm{~m}$ from remnant trees) (RT); (3) in the dispersed retention under medium or fine size $(<10 \mathrm{~cm})$ woody debris (D) resulting from harvesting operations; (4) in the dispersed retention over secondary roads generated by the skidders during harvesting (R); (5) in the dispersed retention with $>50 \%$ understory cover dominated by monocots (MONO); (6) in the dispersed retention with $>50 \%$ understory cover dominated by dicots (DICO); and (7) in the dispersed retention with $<50 \%$ understory cover (DR). In each stand, the percentage of area occupied by each microenvironment was estimated using a $5 \times 5 \mathrm{~m}$ systematic grid per hectare, and census of understory plants was conducted according to methods proposed by Soler et al. (2012).

\section{Regeneration measurements}

A total of 105 regeneration plots of $1 \mathrm{~m}^{2}$ were recorded: 3 stands $\times 7$ microenvironments $\times 5$ replicas. Plots were located in homogeneous patches with similar understory and environment variables. The plots were selected among those identified in the previous characterization of each stand. For this work, regeneration measurements included seedlings (1-year-old plants) and saplings (plants with 2 or more years and less than 1.3-m height).
In each plot, density ( $R D$, thousand $h^{-1}$ ), height ( $R H$, $\mathrm{cm}$ ), and age (RA, years) of each plant were measured. Age was determined in the field from annual stem growth (Cuevas 2000; Gea et al. 2004), and plants' height was measured from the base to the top of the longest extended shoot. Mean annual height growth (RG, $\mathrm{cm}$ year $^{-1}$ ) of each plant was calculated using individual total height and age. Natural browsing of Lama guanicoe was recorded in the study area (Soler et al. 2012) that may affect growth and biometry values. In each plot, a dominant plant (identified as the tallest one) of 4 years old was selected during middle summer (January) to measure, and leaf conductance (LC, mmol m${ }^{-2} \mathrm{~s}^{-1}$ ) using a steady-state leaf porometer (SC-1, Decagon Devices Inc., Pullman, Washington, USA) during the first 3 $\mathrm{h}$ after dawn. The color of the first top expanded leaf was determined using a Munsell Color Chart (Munsell Color Co., Baltimore, USA). A destructive sampling was conducted to measure seedling height $(H, \mathrm{~cm})$, root length $(\mathrm{RL}, \mathrm{cm})$, number of leaves $(L)$, and leaf area (LA, $\mathrm{cm}^{2}$ ). The above and below ground components of each plant were classified and dried in a forced draft oven at $65^{\circ} \mathrm{C}$ until constant weight and weighted to determine $( \pm 0.0001 \mathrm{~g})$ leaves' weight (LW, g), stem weight (SW, g), fine root weight (FRW, g) $(<1 \mathrm{~mm}$ width), and gross root weight (GRW, g) (>1 mm width). Using these data, above ground weight (AGW, g), below ground weight (BGW, g), total weight (TW, g), and the ratio between above and below ground weight (RW) were obtained.

\section{Forest structure and environmental data}

Distance from plots to the aggregate edge (DIST, m), basal area $\left(\mathrm{BA}, \mathrm{m}^{2} \mathrm{ha}^{-1}\right.$ ) using a Criterion RD-1000 (Laser Technology, USA) with a variable $K$ between 3 
and 7, and volumetric soil water content (VSW, \%) using a MP406 moisture probe (ICT, Australia) was measured in each regeneration plot during middle summer (January). To characterize canopy structure and solar radiation transmission, hemispherical photographs of forest canopy were taken in each regeneration plot at ground level with an 8-mm fisheye lens (Sigma, Japan) mounted on a $35-\mathrm{mm}$ digital camera (Nikon, Japan) with a tripod leveling head to ensure horizontal lens position. Each photograph was orientated with the upper edge towards the magnetic north. The best photographs were the ones taken when there was no direct sunshine under evenly overcast skies or cloudless days. Gap Light Analyzer software v.2.0 (Robison and McCarthy 1999; Frazer et al. 2001) was used to define cover (overstory and debris) (CC, \%) as a percentage of open sky relative to the cover, effective leaf area index (LAI) integrated over the zenith angles $0-60^{\circ}$ (Stenburg et al. 1994), and global radiation (GR, $\mathrm{W} \mathrm{m}^{-2}$ ) at ground level (November to March), as the amount of direct (DIRR, $\mathrm{W} \mathrm{m}^{-2}$ ) and diffuse (DIFR, $\mathrm{W} \mathrm{m}^{-2}$ ) radiation transmitted through canopy and debris. The user-supplied input variables and radiation details were presented in Martínez Pastur et al. (2011a, 2011b). Besides this, photosynthetically active radiation

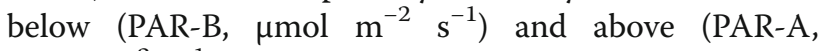
$\mu \mathrm{mol} \mathrm{m} \mathrm{m}^{-2} \mathrm{~s}^{-1}$ ) understory plants and debris were measured with an AccuPAR LP-80 Ceptometer (Decagon Devices Inc., Pullman, Washington, USA).

\section{Statistical analyses}

Multiple ANOVAs were conducted using treatments (AR, RT, DR, R, MONO, DICO, D) and stands (1, 2, 3 ) as the main factors to analyze forest structure (DIST, BA, CC, LAI), environmental variables (VSW, DIFR, DIRR, GR, PAR-B, PAR-A), biometric values of seedlings (H, RL, L, LA), biomass allocation (LW, SW, FRW, GRW, AGW, BGW, TW, RW), eco-physiological variables of seedling (LC), and regeneration values (RD, RA, RH, RG). A post hoc Tukey's test was used for all mean comparisons $(p<$ 0.05 ). Multivariate analyses were also performed with the regeneration variables: (1) classification analyses using complete linkage and Euclidean distances and (2) canonical correspondence analyses (CCA) (Ter Braak and Šmilauer 2002). The significance of the linear gradient CCA ordination was tested using Monte Carlo techniques. In the ordination, plots were classified according to microenvironment treatments and stands.

\section{Results}

Microenvironment characterization

In the harvested stands, retained aggregates occupied $26.2 \pm 2.4 \%$ (average \pm standard deviation) of the area. In the dispersed retention areas, $18.7 \pm 1.7 \%$ of the surface was covered by debris, and $3.3 \pm 2.2 \%$ was affected by skidder roads when timber logs were extracted, while retained live trees influence reaches to $6.1 \pm 2.4 \%$ of the area. The remaining area, without the influence of remnant overstory trees, roads, or debris accumulation, had a significant dominance of monocot plants $(16.0 \% \pm$ 6.4\%) (Poa pratensis $>$ Uncinia lechleriana $>$ Phleum alpinum) than dicot plants $(9.9 \pm 0.8 \%)$ with less than $30-\mathrm{cm}$ height (Galium aparine $>$ Osmorhiza depauperata $>$ Dysopsis glechomoides $>$ Acaena ovalifolia $>$ Cerastium fontanum) than areas with litter or less than $50 \%$ of plant cover $(19.8 \pm 6.8 \%)$.

The sampling of regeneration plot treatments was equally distanced from aggregated edges but was located at longer distances in stand 1 than stand 2 and 3. Basal area and LAI were significantly higher inside the aggregates $\left(77.5 \mathrm{~m}^{2} \mathrm{ha}^{-1}\right.$ and 1.85 , respectively) than in the treatments located in the dispersed retention (12.2-19.0 $\mathrm{m}^{2} \mathrm{ha}^{-1}$ and $0.33-0.68$, respectively). Crown cover of the remnant overstory also presented maximum values in $\mathrm{AR}$, followed by $\mathrm{D}$ and $\mathrm{RT}$, and presented the lower values at DR. These CC values were directly related to VSW and radiation values. Lower values of VSW were found in $\mathrm{AR}$ and $\mathrm{RT}<\mathrm{D}$ and $\mathrm{DICO}<\mathrm{MONO}$ and $\mathrm{R}<$ DR. Global radiation values were maxima in $\mathrm{DR}$ and $\mathrm{R}>$ MONO, DICO and D $>$ RT $>A R$, where $R$ had higher DIRF, and DR had higher DIRR. Photosynthetically active radiation above and below understory plants and debris changed according to the treatments, where greater differences between above and below were found under RT $(37.9 \%)>\operatorname{DICO}(27.7 \%)>\operatorname{MONO}(20.5 \%)>$ DR $\quad(16 \%)>\mathrm{D} \quad(15.8 \%)>\mathrm{R} \quad(10 \%)>\mathrm{AR} \quad$ (no changes) (Table 1). The sampled stands presented significant differences of VSW (stand $2>$ stand $1>$ stand 3 ) and average values of PAR-A was lower in stand 1 than the other treatments. Interactions ocurred due to greater (BA, DIFR, DIFR, GR, PAR-A) or lower (CC, LAI) values found in AR compared to the other microenvironments for stand 1, which presented the lower values of basal area in the dispersed retention. The studied microenvironments offered different amounts of VSW and GR for regeneration (Fig. 2). AR showed lowest VSC and GR values, while RT increased the GR but maintaining the VSW levels. The other microenvironments gradually increased VSW and GR values and following the gradient $\mathrm{D}<\mathrm{DICO}<\mathrm{MONO}<\mathrm{R}<\mathrm{DR}$.

\section{Regeneration characterization in the different microenvironments}

Significant differences were found in biometric and biomass compartmentalization plants variables growing at different microenvironments (Table 2). Bigger plants were found under DICO and $D$ (>33-cm height) with 
Table 1 Multiple ANOVAs and means for regeneration treatments (AR aggregated retention, RT near a remnant tree in the dispersed retention, DR dispersed retention, R roads, MONO under monocot plants, DICO under dicot plants, D under debris) and stands for distance to aggregate edge (DIST, $\mathrm{m})$, basal area (BA, $\left.\mathrm{m}^{2} \mathrm{ha}^{-1}\right)$, crown and debris cover (CC, \%), leaf area index (LAI), volumetric soil water content (VSW, \%), diffuse radiation (DIFR, $\mathrm{W} \mathrm{m}^{-2}$ ), direct radiation (DIRR, $\mathrm{W} \mathrm{m}^{-2}$ ), global radiation $\left(G R, W \mathrm{~m}^{-2}\right.$ ),

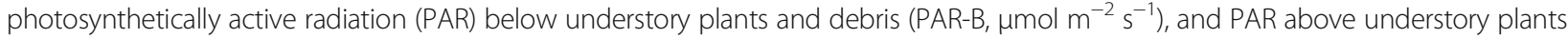
and debris (PAR-A, $\mu \mathrm{mol} \mathrm{m}^{-2} \mathrm{~s}^{-1}$ )

\begin{tabular}{|c|c|c|c|c|c|c|c|c|c|c|c|}
\hline & & DIST & BA & CC & LAI & VSW & DIFR & DIRR & $\mathrm{GR}$ & PAR-B & PAR-A \\
\hline \multirow[t]{9}{*}{ Treatment } & $A R$ & 18.7 & $77.5 \mathrm{~b}$ & $72.65 c$ & $1.85 \mathrm{~b}$ & $23.7 \mathrm{a}$ & $2.3 \mathrm{a}$ & $9.5 \mathrm{a}$ & $11.8 \mathrm{a}$ & $3.6 \mathrm{a}$ & $3.6 \mathrm{a}$ \\
\hline & RT & 20.9 & $17.6 \mathrm{a}$ & $51.61 \mathrm{~b}$ & $0.64 a$ & $25.7 \mathrm{a}$ & $4.0 \mathrm{~b}$ & $18.3 \mathrm{~b}$ & $22.4 b$ & $50.6 \mathrm{de}$ & $88.5 d$ \\
\hline & DR & 23.0 & $12.2 \mathrm{a}$ & $40.54 \mathrm{a}$ & $0.33 \mathrm{a}$ & $41.2 \mathrm{C}$ & $4.8 \mathrm{bc}$ & $23.2 \mathrm{c}$ & $28.1 \mathrm{C}$ & $69.3 \mathrm{e}$ & $82.4 \mathrm{~d}$ \\
\hline & $\mathrm{R}$ & 20.0 & $16.0 \mathrm{a}$ & $44.08 \mathrm{ab}$ & $0.40 \mathrm{a}$ & 39.6 bc & $5.5 \mathrm{C}$ & $22.3 b c$ & $27.8 \mathrm{c}$ & $65.7 \mathrm{de}$ & $75.7 \mathrm{~cd}$ \\
\hline & MONO & 21.6 & $13.6 \mathrm{a}$ & $46.60 a b$ & $0.56 \mathrm{a}$ & 38.4 bc & $4.7 \mathrm{bc}$ & 20.9 bc & $25.7 b c$ & $48.6 \mathrm{~cd}$ & $69.1 \mathrm{~cd}$ \\
\hline & DICO & 20.1 & $19.0 \mathrm{a}$ & $48.42 \mathrm{ab}$ & $0.58 \mathrm{a}$ & $31.3 \mathrm{ab}$ & $4.2 \mathrm{bc}$ & $20.4 b c$ & $24.6 \mathrm{bc}$ & $24.7 b$ & $52.4 \mathrm{bc}$ \\
\hline & $D$ & 20.7 & $13.0 \mathrm{a}$ & $52.32 \mathrm{~b}$ & $0.68 \mathrm{a}$ & $31.2 \mathrm{ab}$ & $4.6 \mathrm{bc}$ & $19.1 \mathrm{bc}$ & $23.7 b c$ & $29.0 \mathrm{bc}$ & $44.8 \mathrm{~b}$ \\
\hline & $F$ & 0.66 & 84.36 & 17.62 & 16.57 & 9.48 & 10.63 & 21.20 & 19.85 & 25.42 & 27.69 \\
\hline & (p) & 0.682 & $<0.001$ & $<0.001$ & $<0.001$ & $<0.001$ & $<0.001$ & $<0.001$ & $<0.001$ & $<0.001$ & $<0.001$ \\
\hline \multirow[t]{5}{*}{ Stand } & 1 & $24.7 b$ & 22.30 & 52.69 & 0.81 & $33.8 \mathrm{ab}$ & 4.3 & 18.2 & 22.5 & 39.3 & $46.9 \mathrm{a}$ \\
\hline & 2 & $19.7 \mathrm{a}$ & 24.30 & 48.78 & 0.66 & $35.4 \mathrm{~b}$ & 4.5 & 20.0 & 24.5 & 45.1 & $68.8 \mathrm{~b}$ \\
\hline & 3 & $18.1 \mathrm{a}$ & 25.80 & 51.20 & 0.69 & $29.8 \mathrm{a}$ & 4.1 & 19.1 & 23.2 & 40.5 & $62.6 \mathrm{~b}$ \\
\hline & F & 10.65 & 1.09 & 1.47 & 1.05 & 3.89 & 0.98 & 1.82 & 1.55 & 1.01 & 9.63 \\
\hline & (p) & $<0.001$ & 0.339 & 0.236 & 0.354 & 0.024 & 0.379 & 0.168 & 0.218 & 0.369 & $<0.001$ \\
\hline \multirow[t]{2}{*}{ Interaction } & $F$ & 0.99 & 3.08 & 3.11 & 2.31 & 1.33 & 2.57 & 3.70 & 3.48 & 1.47 & 2.69 \\
\hline & (p) & 0.468 & 0.001 & 0.001 & 0.013 & 0.219 & 0.006 & $<0.001$ & $<0.001$ & 0.152 & 0.004 \\
\hline
\end{tabular}

$F$ Fisher's test, $(p)$ probability. Letters indicate differences using Tukey's test $(p<0.05)$. Text in italics is used to differentiate between the value of statistical parameter $(F$ and $p)$ and other values

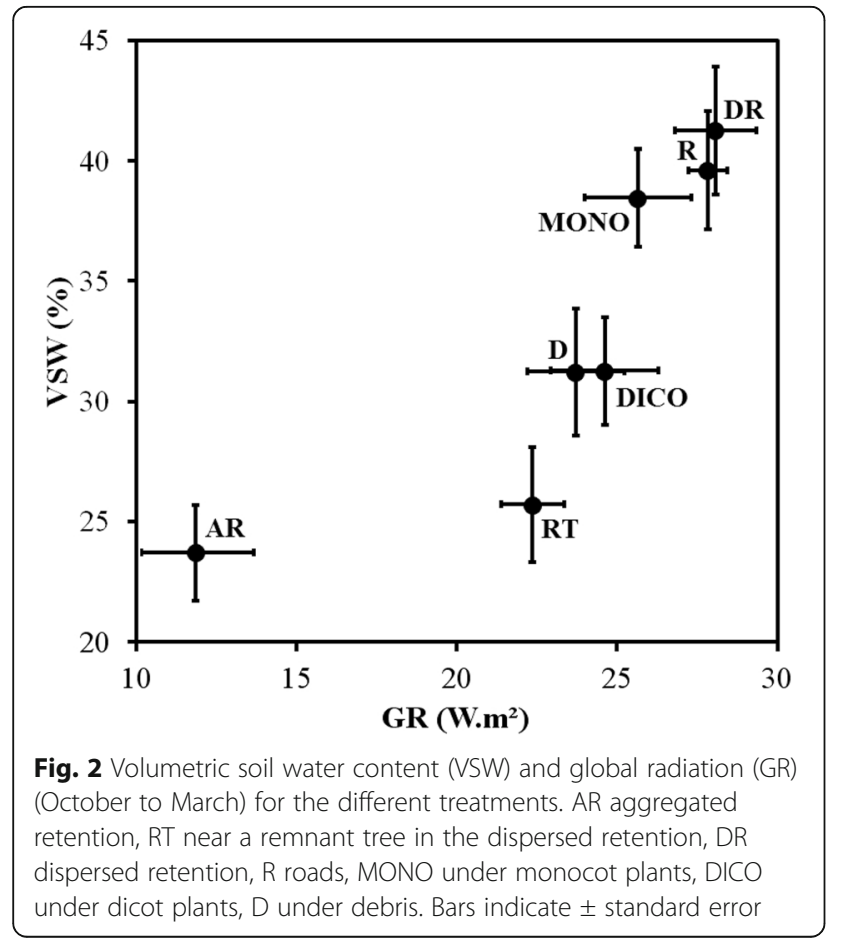

higher leaf area $\left(>108 \mathrm{~cm}^{2}\right)$ compared to AR or RT $(<$ 13-cm height and $<42 \mathrm{~cm}^{2}$, respectively). Plants growing at DR generated more leaves than the other treatments $(\mathrm{DICO}>\mathrm{D}>\mathrm{MONO}>\mathrm{R}>\mathrm{RT}>\mathrm{AR})$, where plants growing in the dispersed presented lower size of leaves $(0.83-$ $0.96 \mathrm{~cm}^{2}$ leaf $\left.^{-1}\right)$, except under D $\left(1.31 \mathrm{~cm}^{2}\right.$ leaf $\left.^{-1}\right)$, compared to AR $\left(1.40 \mathrm{~cm}^{2}\right.$ leaf $\left.^{-1}\right)$. These values were related to the above ground weight (leaves + stem), where higher values were found under $D>\mathrm{DICO}$ than $\mathrm{DR}>$ $\mathrm{MONO}>\mathrm{R}>\mathrm{RT}>\mathrm{AR}$. Root length was maximum under $\mathrm{DICO}$ than under $\mathrm{DR}>\mathrm{D}>\mathrm{MONO}>\mathrm{RT}>\mathrm{R}>\mathrm{AR}$. Fine and gross root weight was significantly lower under $A R$ compared to the treatments of the dispersed retention $(\mathrm{DICO}>\mathrm{DR}>\mathrm{D}$ presented the higher below ground weight values). Total weight was also maximum under DICO and D compared to DR $>$ MONO than $\mathrm{R}>\mathrm{RT}$ than AR, where the ratio between above and below ground weight followed the same trend from values of 2.0-1.1. No significant differences were found in leaf conductance among treatments. Significant differences were also found in most of the studied variables of regeneration growing at different stands (Table 2). Stand 3 presented the lower values of biometric and biomass compartmentalization variables and the highest value in leaf conductance. However, no significant interactions were found for these analyses. Finally, leaves' color 
Table 2 Multiple ANOVAs and means for regeneration treatments (AR aggregated retention, RT near a remnant tree in the dispersed retention, DR dispersed retention, R roads, MONO under monocot plants, DICO under dicot plants, D under debris) and stands for: height $(\mathrm{H}, \mathrm{cm})$, root length $(R L, c m)$, number of leaves $(L)$, leaf area $\left(L A, \mathrm{~cm}^{2}\right)$, leaves' weight $(\mathrm{LW}, \mathrm{g})$, stem weight $(\mathrm{SW}, \mathrm{g})$, fine root weight (FRW, g), gross root weight (GRW, g), above ground weight (AGW, g), below ground weight (BGW, g), total weight $(T W, g)$, ratio between above and below ground weight (RW), and leaf conductance (LC, $\mathrm{mmol} \mathrm{m}^{-2} \mathrm{~s}^{-1}$ )

\begin{tabular}{|c|c|c|c|c|c|c|c|c|c|c|c|c|c|c|}
\hline & & $\mathrm{H}$ & $R L$ & L & LA & LW & SW & FRW & GRW & AGW & BGW & TW & RW & LC \\
\hline \multirow[t]{9}{*}{ Treatment } & $A R$ & $11.1 \mathrm{a}$ & $17.9 \mathrm{a}$ & $14.2 \mathrm{a}$ & $19.95 \mathrm{a}$ & $0.15 a$ & $0.24 \mathrm{a}$ & $0.07 \mathrm{a}$ & $0.28 \mathrm{a}$ & $0.39 \mathrm{a}$ & $0.35 \mathrm{a}$ & $0.74 \mathrm{a}$ & $1.22 \mathrm{ab}$ & 40.0 \\
\hline & RT & $13.1 \mathrm{a}$ & $24.3 \mathrm{abc}$ & $48.8 \mathrm{ab}$ & $41.65 \mathrm{ab}$ & $0.42 a b$ & $0.65 a b$ & $0.22 \mathrm{ab}$ & $0.75 a b$ & $1.07 \mathrm{ab}$ & $0.97 \mathrm{ab}$ & $2.04 \mathrm{ab}$ & $1.07 \mathrm{a}$ & 64.5 \\
\hline & DR & $24.4 b c$ & $31.1 \mathrm{~cd}$ & $118.9 \mathrm{c}$ & $103.04 \mathrm{~cd}$ & $0.91 \mathrm{~cd}$ & $1.80 \mathrm{bc}$ & $0.36 \mathrm{~b}$ & $1.56 \mathrm{~cd}$ & $2.71 \mathrm{~cd}$ & $1.92 \mathrm{~cd}$ & $4.62 \mathrm{~cd}$ & $1.37 \mathrm{ab}$ & 95.4 \\
\hline & $R$ & $20.6 a b$ & $23.1 \mathrm{ab}$ & $71.5 \mathrm{bc}$ & $59.82 \mathrm{abc}$ & $0.55 a b c$ & $1.07 \mathrm{abc}$ & $0.32 \mathrm{~b}$ & $0.89 a b c$ & $1.61 \mathrm{abc}$ & $1.20 b c$ & $2.82 \mathrm{abc}$ & $1.26 a b$ & 63.4 \\
\hline & MONO & $24.5 b c$ & $27.3 \mathrm{bcd}$ & 80.2 bc & 69.15 bc & $0.64 \mathrm{bcd}$ & $1.88 \mathrm{bc}$ & $0.22 \mathrm{ab}$ & $1.35 \mathrm{bcd}$ & $2.52 \mathrm{bcd}$ & $1.57 \mathrm{bcd}$ & $4.09 \mathrm{bcd}$ & $1.67 \mathrm{ab}$ & 83.8 \\
\hline & DICO & $33.3 \mathrm{c}$ & $32.2 \mathrm{~d}$ & $113.3 \mathrm{c}$ & $108.30 \mathrm{~cd}$ & $0.91 \mathrm{~cd}$ & $2.42 d$ & $0.41 \mathrm{~b}$ & $1.78 \mathrm{~d}$ & $3.33 \mathrm{~d}$ & $2.19 \mathrm{~d}$ & $5.52 \mathrm{~d}$ & $1.90 \mathrm{ab}$ & 78.1 \\
\hline & D & $33.9 c$ & $29.6 \mathrm{bcd}$ & $104.1 \mathrm{C}$ & $137.07 \mathrm{~d}$ & $1.00 \mathrm{~d}$ & $2.61 \mathrm{~d}$ & $0.39 \mathrm{~b}$ & $1.43 \mathrm{~cd}$ & $3.61 \mathrm{~d}$ & $1.82 \mathrm{~cd}$ & $5.44 \mathrm{~d}$ & $2.03 \mathrm{~b}$ & 58.5 \\
\hline & $F$ & 13.18 & 9.04 & 10.89 & 12.91 & 10.53 & 10.67 & 5.74 & 10.97 & 11.17 & 11.49 & 12.08 & 2.85 & 2.12 \\
\hline & (p) & $<0.001$ & $<0.001$ & $<0.001$ & $<0.001$ & $<0.001$ & $<0.001$ & $<0.001$ & $<0.001$ & $<0.001$ & $<0.001$ & $<0.001$ & 0.014 & 0.059 \\
\hline \multirow[t]{5}{*}{ Stand } & 1 & $25.0 \mathrm{~b}$ & $28.5 \mathrm{~b}$ & $94.4 \mathrm{~b}$ & 94.14 b & $0.75 \mathrm{~b}$ & $1.82 \mathrm{~b}$ & $0.35 \mathrm{~b}$ & $1.31 \mathrm{~b}$ & $2.57 \mathrm{~b}$ & $1.67 \mathrm{~b}$ & $4.24 \mathrm{~b}$ & 1.53 & $59.9 a$ \\
\hline & 2 & $24.6 \mathrm{ab}$ & $28.5 \mathrm{~b}$ & $84.0 \mathrm{~b}$ & $81.19 \mathrm{~b}$ & $0.69 \mathrm{ab}$ & $1.67 \mathrm{ab}$ & $0.30 \mathrm{ab}$ & $1.23 \mathrm{ab}$ & $2.36 \mathrm{ab}$ & $1.53 \mathrm{~b}$ & $3.89 \mathrm{~b}$ & 1.66 & $61.6 \mathrm{a}$ \\
\hline & 3 & $19.3 \mathrm{a}$ & $22.5 \mathrm{a}$ & $57.8 \mathrm{a}$ & $55.66 \mathrm{a}$ & $0.52 \mathrm{a}$ & $1.07 \mathrm{a}$ & $0.19 a$ & $0.90 \mathrm{a}$ & $1.60 \mathrm{a}$ & $1.09 a$ & $2.70 \mathrm{a}$ & 1.33 & $85.9 \mathrm{~b}$ \\
\hline & $F$ & 4.00 & 9.94 & 6.33 & 6.84 & 3.66 & 4.81 & 6.26 & 4.31 & 4.81 & 5.93 & 5.68 & 1.31 & 3.16 \\
\hline & (p) & 0.022 & $<0.001$ & 0.003 & 0.002 & 0.030 & 0.010 & 0.003 & 0.016 & 0.011 & 0.004 & 0.005 & 0.275 & 0.047 \\
\hline \multirow[t]{2}{*}{ Interaction } & $F$ & 0.81 & 1.20 & 1.81 & 1.23 & 1.02 & 1.04 & 1.73 & 1.39 & 1.03 & 1.67 & 1.27 & 0.62 & 1.48 \\
\hline & (p) & 0.639 & 0.297 & 0.060 & 0.277 & 0.434 & 0.420 & 0.075 & 0.186 & 0.431 & 0.087 & 0.253 & 0.821 & 0.149 \\
\hline
\end{tabular}

$F$ Fisher's test, $(p)$ probability. Letters indicates differences using Tukey's test $(p<0.05)$. Text in italics is used to differentiate between the value of statistical parameters $(F$ and $p)$ and other values

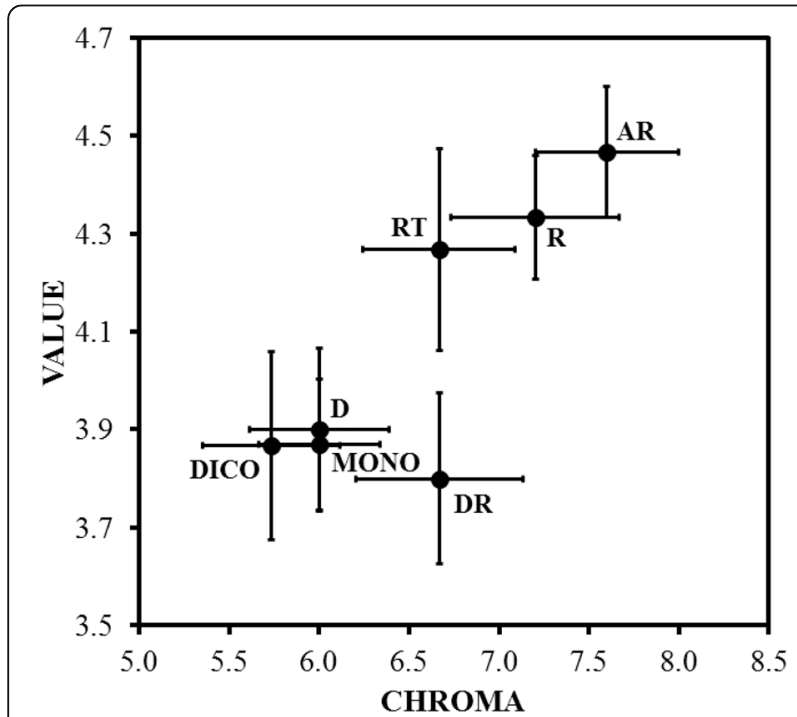

Fig. 3 Leaves' color according Munsell charts (value/chroma) for the different treatments. AR aggregated retention, RT near a remnant tree in the dispersed retention, DR dispersed retention, $\mathrm{R}$ roads, MONO under monocot plants, DICO under dicot plants, D under debris. Bars indicate \pm standard error varied among treatments (Fig. 3), where the group AR, $\mathrm{R}$, and RT presented paler green leaves ( $>$ value and chroma) than (DICO, MONO, D and DR).

\section{Seedling bank characterization in the different microenvironments}

Significant differences were found for the regeneration growing at different microenvironments (Table 3). Plant density was maximum ( $>900$ thousand $\mathrm{ha}^{-1}$ ) in the intact primary forest patches (AR) compared to those treatments located in the dispersed retention (108-197 thousand $\mathrm{ha}^{-1}$ ). The average age of plants increased with the overstory or debris canopy, with lower values measured in RA and higher in DR. Average height of the regeneration followed the same pattern (Table 2). Maximum regeneration height values were found at medium overstory canopy closure or debris. Regeneration growth height was maximum under DICO $>$ D $(>$ $\left.5.7 \mathrm{~cm} \mathrm{year}^{-1}\right)$ than under MONO $\left(4.0 \mathrm{~cm} \mathrm{year}^{-1}\right)$, under $\mathrm{DR}>\mathrm{R}>\mathrm{RT} \quad\left(2.5-3.7 \mathrm{~cm} \quad\right.$ year $\left.^{-1}\right)$ and AR $(<2.0$ $\mathrm{cm}$ year $\left.^{-1}\right)$. Significant differences were found in the studied variables of regeneration growing at different stands (Table 3), where stand 3 presented the lower values. Significant interactions were found for RD and $\mathrm{RH}$ due to some unexpected values. In RD treatment, stand 2 had lower average regeneration densities under DICO and D than stand 3, and in RH treatment, stand 2 
Table 3 Multiple ANOVAs and means for regeneration treatments (AR aggregated retention, RT near a remnant tree in the dispersed retention, DR dispersed retention, $\mathrm{R}$ roads, MONO under monocot plants, DICO under dicot plants, D under debris) and stands for regeneration: density ( $\mathrm{RD}$, thousand ha $\left.{ }^{-1}\right)$, age (RA, years), height $(\mathrm{RH}, \mathrm{cm})$, and growth $\left(\mathrm{RG}, \mathrm{cm}\right.$ year $\left.{ }^{-1}\right)$

\begin{tabular}{|c|c|c|c|c|c|}
\hline & & $\mathrm{RD}$ & RA & $\mathrm{RH}$ & RG \\
\hline \multirow[t]{9}{*}{ Treatment } & AR & 906.9 b & $2.9 a$ & $5.9 \mathrm{a}$ & $1.97 \mathrm{a}$ \\
\hline & RT & $107.8 \mathrm{a}$ & 3.9 bc & $9.7 \mathrm{ab}$ & $2.45 \mathrm{ab}$ \\
\hline & DR & 119.8 a & $4.1 \mathrm{C}$ & 15.6 bc & $3.65 a b$ \\
\hline & $\mathrm{R}$ & $115.1 \mathrm{a}$ & $3.6 \mathrm{~b}$ & $13.4 \mathrm{~b}$ & $3.56 \mathrm{ab}$ \\
\hline & MONO & $158.2 \mathrm{a}$ & $4.0 \mathrm{bc}$ & $16.7 \mathrm{bc}$ & $4.05 \mathrm{bc}$ \\
\hline & DICO & $145.3 \mathrm{a}$ & $4.2 \mathrm{c}$ & $26.9 \mathrm{~d}$ & $6.37 d$ \\
\hline & D & $197.3 \mathrm{a}$ & $3.7 \mathrm{~b}$ & $22.2 \mathrm{~cd}$ & $5.68 \mathrm{~cd}$ \\
\hline & $F$ & 15.57 & 17.42 & 16.99 & 15.50 \\
\hline & (p) & $<0.001$ & $<0.001$ & $<0.001$ & $<0.001$ \\
\hline \multirow[t]{5}{*}{ Stand } & 1 & $270.8 b$ & $4.0 \mathrm{~b}$ & 18.7 b & $4.40 \mathrm{~b}$ \\
\hline & 2 & $372.5 \mathrm{~b}$ & $3.6 \mathrm{a}$ & $15.9 \mathrm{ab}$ & $4.16 a b$ \\
\hline & 3 & 106.8 a & $3.7 \mathrm{a}$ & $12.8 \mathrm{a}$ & $3.33 \mathrm{a}$ \\
\hline & $F$ & 7.69 & 9.88 & 6.73 & 4.51 \\
\hline & (p) & $<0.001$ & $<0.001$ & 0.002 & 0.014 \\
\hline \multirow[t]{2}{*}{ Interaction } & $F$ & 7.57 & 1.18 & 1.98 & 1.79 \\
\hline & (p) & $<0.001$ & 0.309 & 0.036 & 0.062 \\
\hline
\end{tabular}

$F$ Fisher's test; $(p)$ probability. Letters indicates differences using Tukey's test ( $p$ $<0.05)$. Text in italics is used to differentiate between the value of statistical parameters $(F$ and $p$ ) and other values

had higher average regeneration height in $\mathrm{R}$ than the other treatments and stands.

\section{Micro (microenvironments) and macro (stands) scale influence over regeneration}

At a microscale, classification analysis based on measured biometric, eco-physiological, and regeneration variables, split two groups at a Euclidean distance of 200 (Fig. 4a): (1) plants growing under the aggregated retention (AR) and (2) plants growing in different microenvironments under the dispersed retention. At a Euclidean distance of 100 , it was possible to separate two subgroups under the dispersed retention: (1) one represented for the less favorable environments ( $R$ and RT) and (2) one for the best environments (D joint to MONO joint to DICO and DR). At a macroscale, classification analysis split two groups at Euclidean distance of 150 (Fig. 4b): (1) one group formed for stand 1 and 2 and (2) one group for stand 3. Canonical correspondence analyses with the biometric and regeneration variables determined the components of variance of the studied variables (forest structure, environmental, and microenvironment variables) (Fig. 5). Monte Carlo tests showed the following significance for the studied variables (F-ratio, probability): $\operatorname{AR}(103.36,0.002)>\operatorname{DIRR}(7.87,0.002)$ $>\operatorname{DIST}(4.37,0.012)>$ PAR-B $(3.98,0.020)>\mathrm{VSW}$ $(3.43,0.020)>\mathrm{D}(2.26,0.080)>\mathrm{RT}(0.96,0.386)>$ BA $(0.91,0.390)>\operatorname{MONO}(0.90,0.410)>$ PAR-A $(0.87,0.384)>\mathrm{CC}(0.71,0.504)>\operatorname{LAI}(0.67,0.518)>$ $\mathrm{R}(0.66,0.532)>\operatorname{DIFR}(0.48,0.670)>\operatorname{DICO}(0.31$, $0.798)$. Total inertia of the analysis reached to 0.554 . Eigenvalue and correlation of axis 1 were 0.312 and 0.873 and separated the plots according to the retention type (aggregated vs. dispersed) and their influence over the studied variables (e.g., the increase of $\mathrm{CC}$ or LAI inside the aggregates or the increase of GR or VSW in the dispersed retention). Eigenvalue and correlation of axis 2 was 0.025 and 0.501 , and mainly split the plots according to the influence of retained legacies inside the harvested stands, e.g., the distance to the retention patches (DIST), the closeness of the retained trees in the dispersed retention (RT), or the presence of debris (D). When plots were classified according to the microscale (microenvironment treatments) (Fig. 5a), axis 1 separated two groups: (2) one for AR plots and (2) the plots located in the dispersed retention. This second group is continuous, from D in one extreme to RT in the other. When plots were classified according to the macroscale (stand treatments) (Fig. 5b), no separation was defined in axis 1 . However, axis 2 showed a tendency where stand 1 plots were located in the upper area of the graph and stand three plots were located in the lower area of the graph.

\section{Discussion}

Variable retention offered a wide range of microenvironments that favored the establishment of natural regeneration and other species compared with traditional silvicultural practices (Martínez Pastur et al. 2011b, 2013). Competing benefits of different spatial distributions are the main argument for the use of spatially variable overstory retention (e.g., dispersed retention and different levels of aggregation) within a single harvest unit (Franklin et al. 1997). Under this approach, as with any other silvicultural system, regeneration of trees is an essential indicator of management success (Palik et al. 2003).

The retention pattern, both aggregates and dispersed trees, also influenced over regeneration (Martínez Pastur et al. 2011b). The edge effects modified the amount of rainfall and light interception that reach to the forest floor. The influence was proportional to the distance and aspect, while dispersed retention provides positive (shelter and seed source) and negative (water uptake) synergies depending on the tree closeness. In fact, the microenvironments provided by the variable retention can increase or decrease the chances of achieving a 

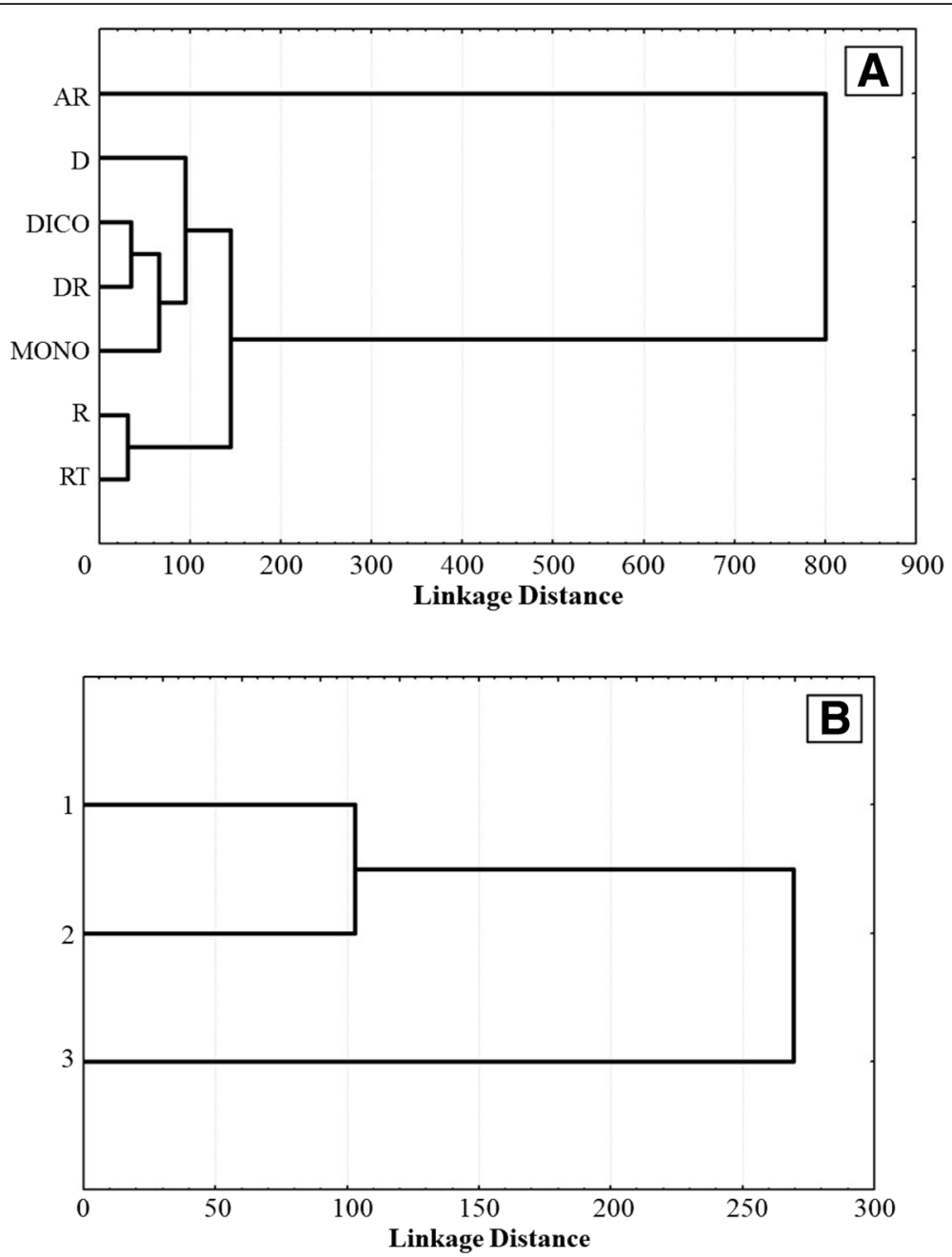

Fig. 4 Classification analysis for the different treatments (a) and stands (b) based on measured biometry, eco-physiology, and regeneration variables. AR aggregated retention, RT near a remnant tree in the dispersed retention, DR dispersed retention, R roads, MONO under monocot plants, DICO under dicot plants, D under debris

successful natural regeneration. In our study, the microenvironments presented great differences between AR and the different treatments of DR, mostly associated with soil moisture and light availability. In other silvicultural treatments, such as shelterwood cuts, create less microenvironments due to the harvesting homogenizes the managed stand (Martínez Pastur et al. 2000). Besides this, many microenvironments in primary forests allowed to maintain a seedling bank that survives for long periods of time (Martínez Pastur et al. 2012; Toro Manríquez et al. 2018). Soil moisture and light availability mainly conditioned the survival of the seedling, and plants quickly reacted after canopy opening. Several studies have shown that harvesting modified the microclimate inside the managed stands (Caldentey et al. 2009; Martínez Pastur et al. 2014). For example, soil moisture and radiation significantly increased in Nothofagus forests (Heinemann et al. 2000; Martínez Pastur et al. 2007a; Martínez Pastur et al. 2014), where photosynthetically active radiation incremented between 2.4 and 2.9 times in harvested forests (Caldentey et al. 2009). According to our results, AR presented similar conditions compared to primary forests (high values of canopy cover, leaf area index, and basal area), and environmental conditions changed when the distance to the edges increases within the dispersed retention (Martínez Pastur et al. 2013). Besides this, dispersed retention presented a high heterogeneity of microenvironments (e.g., accumulation of woody debris, understory composition, and degrees of soil impacts due to harvesting operations), where the similarities and dissimilarities were based on the balance between light and soil moisture availability. In our study, we found that DR, R, and MONO presented the highest levels of light and soil moisture, compared with $\mathrm{D}$ and DICO (medium soil moisture levels), RT (low soil moisture levels), and AR (low light and soil moisture 


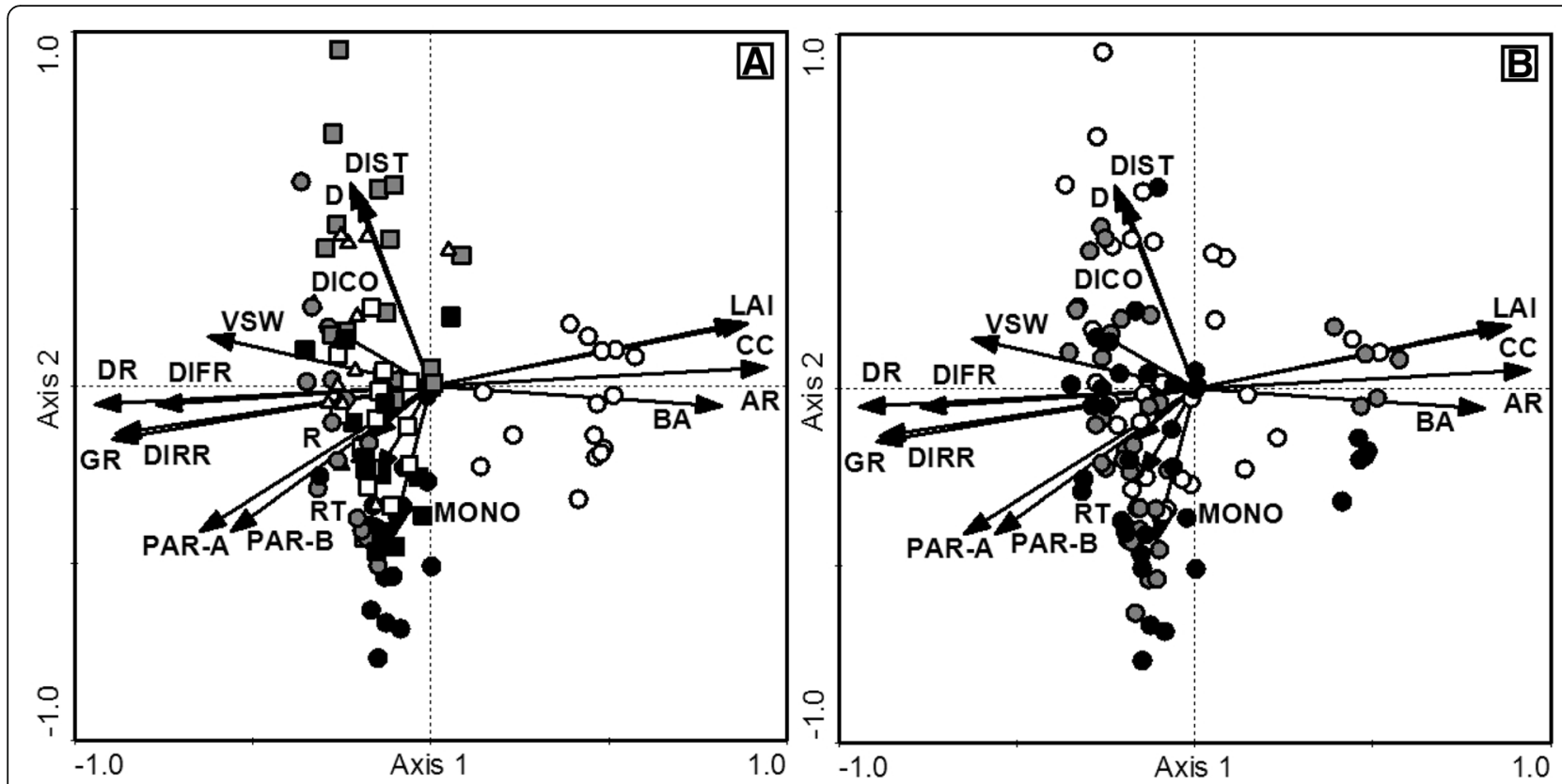

Fig. 5 CCA analysis of the measured biometry and regeneration variables using as explicatory variables: plots inside the aggregated retention (AR), basal area (BA, $\left.\mathrm{m}^{2} \mathrm{ha}^{-1}\right)$, crown and debris cover (CC, \%), plots covered by debris (D), plots with dominance of dicot plants (DICO), diffuse radiation (DIFR, $\mathrm{W} \mathrm{m}^{-2}$ ), direct radiation (DIRR, $\mathrm{W} \mathrm{m}^{-2}$ ), distance to aggregate edge (DIST, $\mathrm{m}$ ), plots located in the dispersed retention (DR), global radiation $\left(\mathrm{GR}, \mathrm{W} \mathrm{m}^{-2}\right.$ ), leaf area index ( $\mathrm{LAl}$ ), plots with dominance of monocot plants (MONO), photosynthetically active radiation (PAR) above understory plants and debris (PAR-A) $\left(\mu \mathrm{mol} \mathrm{m} \mathrm{m}^{-2} \mathrm{~s}^{-1}\right)$, PAR below understory plants and debris (PAR-B) $\left(\mu \mathrm{mol} \mathrm{m}^{-2} \mathrm{~s}^{-1}\right)$, plots located in roads (R), plots located near a remnant tree in the dispersed retention (RT), and volumetric soil water content (VSW, \%). Plots were classified according to the different treatments: a aggregated retention (white dots), dispersed retention (gray dots), near a remnant tree in the dispersed retention (black dots), roads (white square), under debris (gray square), under monocot plants (black square), and under dicot plants (white triangle); b stand 1 (white dots), stand 2 (gray dots), and stand 3 (black dots)

levels). Martínez Pastur et al. (2011b) reported that understory could positively (e.g., Osmorhiza depauperata) or negatively (e.g., Acaena ovalifolia) influence survival, growth, and eco-physiological performance of $N$. pumilio seedlings. For this, the specific composition of the understory layer can influence over regeneration, e.g., MONO offered more light levels than DICO, but the seedling performance (growth and eco-physiology) was lower than other microenvironments. These synergies and trade-offs were also described in other forests, due to the herbaceous layer using large amounts of water for their growth that limits the survival of regeneration plants at the initial stage of growth (Holmgren et al. 2000; Rey Benayas et al. 2005).

Roads allowed to accumulate water in hollows produced by the skidders and offered more light availability due to trees wind-blows affected by harvesting. However, soil densification and the removal of the organic layer decreased the regeneration performance (Martínez Pastur et al. 2007b). Woody debris was also pointed as a critical factor for regeneration success by maintaining higher moisture levels and shelter against animal browsing (Martínez Pastur et al. 2014). The presence of decaying coarse woody debris in gaps of $N$. pumilio forests in northern Patagonia also increased the survival rates due to higher water availability during late summer (Heinemann et al. 2000). Coarse woody debris from the harvesting (rotten wood, small diameter logs, and branches) represented up to $50 \%$ of the harvested volume in $N$. pumilio forests, and usually, it was accumulated next to roads (Martínez Pastur et al. 2011b). However, the excessive woody debris accumulation can limit the regeneration establishment and growth (Martínez Pastur et al. 2007b, 2011b). Some nutrients (e.g., nitrogen) can be immobilized in the early stage of woody debris decomposition by reducing soil nitrogen availability for seedling growth (Zimmerman et al. 1995) in summer due to a higher soil microbial activity (Caldentey et al. 2001). In our study, soil nitrogen content was higher in stand 3, due to a low immobilization (mineral nitrogen to organic nitrogen), and this may be responsible for the low seedling growth compared with the other stands (Martínez Pastur et al. 2014).

Several studies conducted in forests with or without disturbances reported the woody debris as safe sites or nurseries (Kuuluvainen and Kalmari 2003; Bailey et al. 2012) by changing the microclimatic conditions (light and moisture) or favoring the decomposition processes. Kuuluvainen and Kalmari (2003) also indicated that the association of the regeneration with woody debris 
decreased the competition with other plants, mainly in environments susceptible to the grasses invasion.

It is well documented that the existence of a seedling bank before harvesting is a key factor for regeneration process success (Martínez Pastur et al. 2008). N. pumilio is a mid-tolerant species, due to its ability to colonize new environments and its ability to survive under dense tree canopies (Martínez Pastur et al. 2007a). These eco-physiological advantages can explain why the species can develop after large openings (e.g., similar to a clear-cutting) and in other unfavorable conditions for extended periods (e.g., inside AR). The adaptation of $N$. pumilio under different light and moisture levels determines its great plasticity in a wide range of environmental conditions (Lencinas et al. 2007; Martínez Pastur et al. 2007a, 2011c; Peri et al. 2009). In fact, the regeneration dynamics of Nothofagus is adjusted according to the limitation of essential resources (e.g., light, moisture and soil nutrients) that influences on the plants' size (Promis and Allen 2017). These environmental differences affected the ecophysiological performance of plants, e.g., biomass allocation (above- and below-ground) (Martínez Pastur et al. 2014). In AR, the regeneration presented a high regeneration density compared to other treatments. However, the individual biomass was lower compared to the other microenvironments (smaller size of plants, number of leaves, leaf area, stem, roots) with less leaf conductance. The decrease in canopy cover favors the height growth of regeneration, up to $34-45 \%$ (Caldentey et al. 2009; Martínez Pastur et al. 2011a). Our results also indicated that the microenvironment in DR influenced differentially plant growth being under DICO and DR showed the highest. In contrast, large canopy openings expose the seedlings plants to the drying effect of wind that limits the regeneration (McIntire et al. 2016). This reduced plant density in areas of DR, and also, an increase in radiation exposure can lead to the fall of some leaves in response to drought (Cordeiro et al. 2009). Leaf area reduction in drought-stressed plants could be seen as an adaptation strategy by reducing the transpiration rate. However, this strategy may reduce the net photosynthesis of the whole plant (Martínez Pastur et al. 2007a; Cordeiro et al. 2009).

\section{Conclusions}

Microenvironments generated during harvesting by variable retention influence the regeneration dynamics and the individual performance of the established plants in the Nothofagus pumilio forests. Changes in the forest structure (canopy cover and tree density), as well as woody debris accumulation, significantly affect the effective rainfall and the overall radiation that reach the forest floor. Areas covered with medium or fine woody debris and dicot understory plants showed better eco-physiological performance and growth of regeneration, although dispersed retention areas (far away from remnant trees) and roads can also present adequate conditions for regeneration. The proportion of different microenvironments in the harvested areas will determine the success of the natural regeneration after harvesting, and consequently, the success of the proposed silvicultural management. It is necessary to develop new harvesting methods that decrease the unfavorable microenvironments (e.g., road density or excessive woody accumulation) to assure the success of the proposed regeneration method.

\section{Abbreviations}

AGW: Above ground weight ( $L A+L W+S W)(g)$; AR: Microenvironments within the retained aggregates; BA: Basal area $\left(\mathrm{m}^{2} \mathrm{ha}^{-1}\right) ; \mathrm{BGW}$ : Below ground weight (FRW + GRW) (g); CC: Cover (overstory crown and debris) as a percentage of open sky relative to the cover (\%); D: Microenvironments in the dispersed retention under middle or fine woody debris resulting from the harvesting; DICO: Microenvironments in the dispersed retention with > $50 \%$ understory cover dominated by dicots; DIFR: Diffuse radiation transmitted through canopy and debris $\left(\mathrm{W} \mathrm{m}^{-2}\right)$; DIRR: Direct radiation transmitted through canopy and debris $\left(\mathrm{W} \mathrm{m}^{-2}\right)$; DIST: Distance to aggregate edge (m); DR: Microenvironments in the dispersed retention with $<50 \%$ understory cover; FRW: Fine root weight ( $<1 \mathrm{~mm}$ width) of destructive sampling plant (dried at $65^{\circ} \mathrm{C}$ ) (g); GR: Global radiation at ground level $\left(\mathrm{W} \mathrm{m}^{-2}\right)$; GRW: Gross root weight (> $1 \mathrm{~mm}$ width) of destructive sampling plant (dried at $\left.65^{\circ} \mathrm{C}\right)(\mathrm{g})$; H: Height of destructive sampling plant $(\mathrm{cm})$; L: Number of leaves of destructive sampling plant; LA: Leaf area of destructive sampling plant (dried at $\left.65^{\circ} \mathrm{C}\right)\left(\mathrm{cm}^{2}\right)$; LAl: Effective leaf area index; LC: Leaf conductance in plant with 4 years old $\left(\mathrm{mmol} \mathrm{m}^{-2} \mathrm{~s}^{-1}\right)$; LW: Leaves weight of destructive sampling plant (dried at $\left.65^{\circ} \mathrm{C}\right)(\mathrm{g})$; MONO: Microenvironments in the dispersed retention with $>50 \%$ understory cover dominated by monocots; PAR-A: Photosynthetically active radiation above $\left(\mu \mathrm{mol} \mathrm{m} \mathrm{m}^{-2} \mathrm{~s}^{-1}\right)$; PAR-B: Photosynthetically active radiation below $\left(\mu \mathrm{mol} \mathrm{m} \mathrm{m}^{-2} \mathrm{~s}^{-1}\right)$; R: Microenvironments in the dispersed retention over the secondary roads produced by skidders during harvesting; RA: Regeneration plant aged (years); RD: Regeneration plant density (thousand ha ${ }^{-1}$ ); RG: Mean annual height growth of each plant ( $\mathrm{cm}$ year $\left.{ }^{-1}\right)$; $\mathrm{RH}$ : Regeneration plant height $(\mathrm{cm})$; RL: Root length of destructive sampling plant $(\mathrm{cm})$;

RT: Microenvironments in the dispersed retention within the influence area of remnant overstory trees ( $<2 \mathrm{~m}$ from the base of a retained tree); RW: Ratio between above and below ground weight; SW: Stem weight of destructive sampling plant (dried at $\left.65^{\circ} \mathrm{C}\right)(\mathrm{g})$; TW: Total weight (AGW + BGW) (mg); VSW: Volumetric soil water content (\%)

\section{Acknowledgements}

The authors gratefully thank the Centro Austral de Investigaciones Científicas, Ricardo Vukasovic of Servicios Forestales Consultancy, Los Cerros Ranch, and Kareken sawmill for their support during the realization of this work. We acknowledge the funding sources (2009-2011) of MIA-CATIE project (fondo de apoyo a proyectos de investigación en mitigación y adaptación al cambio climático en la gestión forestal sostenible).

\section{Funding}

MIA-CATIE project (fondo de apoyo a proyectos de investigación en mitigación y adaptación al cambio climático en la gestión forestal sostenible) (2009-2011).

\section{Availability of data and materials}

At CADIC repository

\section{Authors' contributions}

GJMP, PLP, and KAPR designed the study and collaborated in the analyses of the results. GJMP, JMC, and MVL participate in the data taking. MVL conducted the multivariate analyses. MDRTM together with the rest of the authors wrote the manuscript. All authors read and approved the final manuscript. 


\section{Authors' information}

No additional information.

\section{Ethics approval and consent to participate}

No ethics or conflict of interest exists.

\section{Consent for publication}

The authors consent to publish the data included in this draft.

\section{Competing interests}

The authors declare that they have no competing interests.

\section{Publisher's Note}

Springer Nature remains neutral with regard to jurisdictional claims in published maps and institutional affiliations.

\begin{abstract}
Author details
${ }^{1}$ Centro Austral de Investigaciones Científicas (CADIC), Consejo Nacional de Investigaciones Científicas y Técnicas (CONICET), Houssay 200 (9410), Ushuaia, Tierra del Fuego, Argentina. ${ }^{2}$ Laboratorio de Investigaciones en Maderas (LIMAD), Universidad Nacional de la Plata (UNLP), Diagonal $113 \mathrm{n}^{\circ}$ 469 (1904) La Plata, Buenos Aires, Argentina. ${ }^{3}$ Instituto Nacional de Tecnología Agropecuaria (INTA), Universidad Nacional de la Patagonia Austral (UNPA), Consejo Nacional de Investigaciones Científicas y Técnicas (CONICET), cc 332 (9400), Río Gallegos, Santa Cruz, Argentina. ${ }^{4}$ Departamento de Silvicultura y Conservación de la Naturaleza, Facultad de Ciencias Forestales y de Conservación de la Naturaleza, Universidad de Chile, cc 9206, Santiago, Chile.
\end{abstract}

\section{Received: 6 February 2019 Accepted: 7 May 2019}

\section{Published online: 18 June 2019}

\section{References}

Bailey T, Davidson N, Close D (2012) Understanding the regeneration niche: microsite attributes and recruitment of eucalypts in dry forests. For Ecol Manag 269:229-238. https://doi.org/10.1016/j.foreco.2011.12.021

Blood LE, Titus JH (2010) Microsite effects on forest regeneration in a bottomland swamp in western New York. J Torrey Bot Soc 137:88-102. https://doi.org/10. 3159/08-RA-062.1

Burgess D, Wetzel S (2000) Nutrient availability and regeneration response after partial cutting and site preparation in eastern white pine. For Ecol Manag 138:249-261. https://doi.org/10.1016/S0378-1127(00)00400-X

Caldentey J, Mayer H, Ibarra M, Promis A (2009) The effects of a regeneration felling on photosynthetic photon flux density and regeneration growth in a Nothofagus pumilio forest. Eur J Forest Res 128:5-84. https://doi.org/10.1007/ s10342-008-0240-8

Catovsky S, Bazzaz F (2002) Nitrogen availability influences regeneration of temperate tree species in the understory seedling bank. Ecol Appl 12(4): 1056-1070. https://doi.org/10.2307/3061036

Christie D, Armesto J (2003) Regeneration microsites and tree species coexistence in temperate rain forest of Chiloé Island, Chile. J Ecol 91(5):776784. https://doi.org/10.1046/j.1365-2745.2003.00813.x

Cordeiro Y, Pinheiro H, dos Santos FB, Correa S, Silva J, Dias-Filho M (2009) Physiological and morphological responses of young mahogany (Swietenia macrophylla King) plants to drought. For Ecol Manag 258:1449-1455. https:// doi.org/10.1016/j.foreco.2009.06.054

Cuevas JG (2000) Tree recruitment at the Nothofagus pumilio alpine timberline in Tierra del Fuego, Chile. J Ecol 88:840-855 doi: 0.1046/j. 1365-2745.2000.00497.x

Dreiss LM, Volin JC (2013) Influence of leaf phenology and site nitrogen on invasive species establishment in temperate deciduous forest understories. For Ecol Manag 296:1-8. https://doi.org/10.1016/j.foreco.2013.01.031

Franklin JF, Berg DR, Thornburgh DA, Tappeiner JC (1997) Alternative silvicultural approaches to timber harvesting: variable retention harvest systems. In: Kohm KA, Franklin JF (eds) Creating a forestry for the $21^{\text {st }}$ Century. Island Press, Washington, DC, pp 111-139

Frazer GW, Fournier RA, Trofymow JA, Gall RJ (2001) A comparison of digital and film fisheye photography for analysis of forest canopy structure and gap light transmission. Agric For Meteorol 109:249-263. https://doi.org/10.1016/ S0168-1923(01)00274-X
Gea G, Martínez Pastur G, Cellini JM, Lencinas MV (2004) Forty years of silvicultural management in southern Nothofagus pumilio (Poepp. et Endl.) Krasser primary forests. For Ecol Manag 201(2-3):335-347. https://doi.org/10. 1016/j.foreco.2004.07.015

Gustafsson L, Baker S, Bauhus J, Beese W, Brodie A, Kouki J, Lindenmayer D, Lõhmus A, Martinez Pastur G, Messier C, Neyland M, Palik B, SverdrupThygeson A, Volney J, Wayne A, Franklin JF (2012) Retention forestry to maintain multifunctional forests: a world perspective. Bioscience 62(7):633645. https://doi.org/10.1525/bio.2012.62.7.6

Heinemann K, Kitzberger T (2006) Effects of position, understorey vegetation and coarse woody debris on tree regeneration in two environmentally contrasting forests of northwestern Patagonia: a manipulative approach. J Biogeogr 33(8):1357-1367. https://doi.org/10.1111/j.1365-2699.2006.01511.x

Heinemann K, Kitzberger T, Veblen T (2000) Influences of gap microheterogeneity on the regeneration of Nothofagus pumilio in a xeric old-growth forest of northwestern Patagonia, Argentina. Can J For Res 30(1):25-31. https://doi. org/10.1139/x99-181

Heithecker TD, Halpern CB (2007) Edge-related gradients in microclimate in forest aggregates following structural retention harvests in western Washington. For Ecol Manag 248:163-173. https://doi.org/10.1016/j.foreco.2007.05.003

Henn JJ, Anderson CB, Kreps G, Lencinas MV, Soler R, Martínez Pastur G (2014) Determining abiotic and biotic drivers that limit active riparian forest restoration in abandoned beaver meadows in Tierra del Fuego. Ecol Restor 32(4):369-378. https://doi.org/10.3368/er.32.4.369

Holmgren M, Segura AM, Fuentes ER (2000) Limiting mechanisms in the regeneration of the Chilean matorral. Plant Ecol 147:49-57. https://doi.org/10. 1023/A:1009804726307

Hörnberg G, Ohlson M, Zackrisson O (1997) Influence of bryophytes and microrelief conditions on Picea abies seed regeneration patterns in boreal old-growth swamp forest. Can J For Res 27(7):1015-1023. https://doi.org/10. 1139/x97-045

Kupferschmid AD, Bugmann H (2005) Effects of microsites, logs and ungulate browsing on Picea abies regeneration in a mountain forest. For Ecol Manag 205:251-265. https://doi.org/10.1016/.fforeco.2004.10.008

Kuuluvainen T, Kalmari R (2003) Regeneration microsites of Picea abies seedlings in a windthrow area of a boreal old-growth forest in southern Finland. Ann Bot Fenn 40:401-413

Lencinas MV, Martínez Pastur G, Moretto A, Gallo E, Busso C (2007) Productividad diferencial de plántulas de Nothofagus pumilio bajo gradientes de luz y humedad del suelo. Bosque 28(3):241-248. https://doi.org/10.4067/S071792002007000300009

Lindenmayer D, Blair D, McBurney L (2019) Variable retention harvesting in Victoria's Mountain Ash (Eucalyptus regnans) forests (southeastern Australia). Ecol Processes 8:2. https://doi.org/10.1186/s13717-018-0156-2

Lindenmayer D, Franklin JF, Lõhmus A, Baker S, Bauhus J, Beese W, Brodie A, Kiehl B, Kouki J, Martínez Pastur G, Messier C, Neyland M, Palik B, SverdrupThygeson A, Volney J, Wayne A, Gustafsson L (2012) A major shift to the retention approach for forestry can help resolve some global forest sustainability issues. Cons Letters 5(6):421-431. https://doi.org/10.1111/j.1755263X.2012.00257.x

Luque S, Martínez Pastur G, Echeverría C, Pacha MJ (2010) Overview of biodiversity loss in South America: a landscape perspective for sustainable forest management and conservation in temperate forests. In: Li C, Lafortezza R, Chen J (eds) Landscape ecology and forest management: challenges and solutions in a changing globe. HEP-Springer, Amsterdam. Chapter 15, pp 352-379

Martínez Pastur G, Cellini JM, Lencinas MV, Barrera M, Peri PL (2011b) Environmental variables influencing regeneration of Nothofagus pumilio in a system with combined aggregated and dispersed retention. For Ecol Manag 261:178-186. https://doi.org/10.1016/j.foreco.2010.10.002

Martínez Pastur G, Cellini JM, Peri PL, Vukasovic R, Fernández C (2000) Timber production of Nothofagus pumilio forests by a shelterwood system in Tierra del Fuego (Argentina). For Ecol Manag 134(1-3):153-162. https://doi.org/10. 1016/S0378-1127(99)00253-4

Martínez Pastur G, Jordán C, Lencinas MV, Soler Esteban R, Ivancich H, Kreps G (2012) Landscape and microenvironmental conditions influence over regeneration dynamics in old-growth Nothofagus betuloides southern Patagonian forests. Plant Biosyst 146(1):201-213. https://doi.org/10.1080/ 11263504.2011 .650725

Martínez Pastur G, Lencinas MV, Cellini JM, Peri P, Soler Esteban R (2009) Timber management with variable retention in Nothofagus pumilio forests of 
southern Patagonia. For Ecol Manag 258:436-443. https://doi.org/10.1016/j. foreco.2009.01.048

Martínez Pastur G, Lencinas MV, Peri P, Arena M (2007a) Photosynthetic plasticity of Nothofagus pumilio seedlings to light intensity and soil moisture. For Ecol Manag 243(2):274-282. https://doi.org/10.1016/j.foreco.2007.03.034

Martínez Pastur G, Lencinas MV, Peri PL, Moretto AS, Cellini JM, Mormeneo I, Vukasovic R (2007b) Harvesting adaptation to biodiversity conservation in sawmill industry: technology innovation and monitoring program. J Tech Manage Innov 2(3):58-70

Martínez Pastur G, Lencinas MV, Soler Esteban R, Ivancich H, Peri PL, Moretto A Hernández L, Lindstrom I (2011c) Plasticidad ecofisiológica de plántulas de Nothofagus pumilio frente a combinaciones de niveles de luz y humedad en el suelo. Ecol Aust 21:301-315

Martínez Pastur G, Peri PL, Cellini JM, Lencinas MV, Barrera M, Ivancich H (2011a) Canopy structure analysis for estimating forest regeneration dynamics and growth in Nothofagus pumilio forests. Ann For Sci 68:587-594. https://doi. org/10.1007/s13595-011-0059-1

Martínez Pastur G, Peri PL, Lencinas MV, Cellini JM, Barrera M, Soler R, Ivancich H, Mestre L, Moretto AS, Anderson CB, Pulido F (2013) La producción forestal y la conservación de la biodiversidad en los bosques de Nothofagus en Tierra del Fuego y Patagonia Sur. In: Donoso P, Promis A (eds) Silvicultura en bosques nativos: avances en la investigación en Chile. Universidad Austral de Chile, Valdivia, Chile, Argentina y Nueva Zelanda, pp 155-179

Martínez Pastur G, Soler R, Cellini JM, Lencinas MV, Peri P, Nayland MG (2014) Survival and growth of Nothofagus pumilio seedlings under several microenvironments after variable retention harvesting in southern Patagonian forests. Ann For Sci 71(3):349-362. https://doi.org/10.1007/ s13595-013-0343-3

McIntire EJB, Piper FI, Fajardo A (2016) Wind exposure and light exposure, more than elevation-related temperature, limit tree line seedling abundance on three continents. J Ecol 104(5):1379-1390. https://doi.org/10.1111/1365-2745. 12599

Messier C, Doucet R, Ruel JC, Claveau Y, Kelly C, Lechowicz MJ (1999) Functional ecology of advance regeneration in relation to light in boreal forests. Can J For Res 29(6):812-823. https://doi.org/10.1139/x99-070

Neyland M, Hickey J, Read SM (2012) A synthesis of outcomes from the Warra silvicultural systems trial, Tasmania, Australia: safety, timber production, economics, biodiversity, silviculture, and social acceptability. Aust For 75:147162. https://doi.org/10.1080/00049158.2012.10676397

Palik B, Mitchell RJ, Pecot S, Battaglia M, Pu M (2003) Spatial distribution of overstorey retention influences resources and growth of longleaf pine seedlings. Ecol Appl 13(3):674-686. https://doi.org/10.1890/1051-0761

Peri P, Martínez Pastur G, Lencinas MV (2009) Photosynthetic and stomatal conductance responses to different light intensities and water status of two main Nothofagus species of south Patagonian forest. For Sci 55(3):101-111. https://doi.org/10.17221/66/2008-JFS

Promis A, Allen RB (2017) Tree seedlings respond to both light and soil nutrients in a Patagonian evergreen-deciduous forest. PLoS One 12(11):e0188686. https://doi.org/10.1371/journal.pone.0188686

Promis A, Caldentey J, Ibarra M (2010) Microclima en el interior de un bosque de Nothofagus pumilio y el efecto de una corta de regeneración. Bosque 31(2): 129-139. https://doi.org/10.4067/S0717-92002010000200006

Rey Benayas JM, Navarro J, Espigares T, Nicolau JM, Zavala MA (2005) Effects of artificial shading and weed mowing in reforestation of Mediterranean abandoned cropland with contrasting Quercus species. For Ecol Manag 212: 302-314. https://doi.org/10.1016/j.foreco.2005.03.032

Rey PJ, Alcántara JM, Sánchez-Lafuente F, Garrido AM, Ramírez JL, Manzaneda AJ (2004) Seedling establishment in Olea europaea: seed size and microhabitat affect growth and survival. Ecoscience 11(3):310-320. https://doi.org/10.1080/ 11956860.2004 .11682838

Robison SA, McCarthy BC (1999) Potential factors affecting the estimation of light availability using hemispherical photography in oak forest understories. Bull Torrey Bot Club 126:344-349

Soler Esteban R, Martínez Pastur G, Lencinas MV, Borrelli L (2012) Forage differential use between native and domestic herbivores in southern Patagonian Nothofagus forests. Agrofor Syst 85(3):397-409. https://doi.org/10 1007/s10457-011-9430-3

Soler Esteban R, Martínez Pastur G, Lencinas MV, Moretto A, Peri PL (2011) Above- and below-ground nutrient tissue concentration and leaf pigment changes in Patagonian woody seedlings grown under light and soil moisture gradients. J Plant Nutr 34:2222-2236. https://doi.org/10.1080/ 01904167.2011 .618580

Stenburg P, Linder S, Smolander HY, Flower-Ellis J (1994) Performance of the LAI2000 plant canopy analyzer in estimating leaf area index of some Scots pine stands. Tree Physiol 14:981-995

Ter Braak CJF, Šmilauer P (2002) CANOCO reference manual and CanoDraw for Windows User's guide: software for canonical community ordination. Version 4.5. Microcomputer Power, Ithaca

Toro Manríquez M, Promis Á, Huertas Herrera A, Martínez Pastur G (2018) Influencia del micrositio y la exposición en la regeneración de bosques de Nothofagus pumilio afectados por Castor canadensis en Tierra del Fuego: un análisis exploratorio. Bosque 39(3):431-440. https://doi.org/10.4067/S071792002018000300431

Torres AD, Cellini JM, Lencinas MV, Barrera MD, Soler Esteban R, Díaz-Delgado R, Martínez Pastur G (2015) Seed production and recruitment in primary and harvested Nothofagus pumilio forests: influence of regional climate and years after cuttings. For Syst 24(1):e-016. https://doi.org/10.5424/fs/2015241-06403

Valenzuela PA, Arellano E, Burger AJ, Becerra P (2016) Using facilitation microsites as a restoration tool for conversion of degraded grasslands to Nothofagus forests in southern Patagonia. Ecol Eng 95(1):580-587. https://doi.org/10. 1016/j.ecoleng.2016.06.116

Vodde F, Jogiste K, Gruson L, llisson T, Koster K, Stanturf JA (2010) Regeneration in windthrow areas in Hemiboreal forests: the influence of microsite on the height growth of different tree species. J For Res 15:55-64. https://doi.org/10. 1007/s10310-009-0156-2

Zimmerman J, Pulliam W, Lodge D, Quiñones-Orfila V, Fetcher N, GuzmánGrajales S, Waide R (1995) Nitrogen immobilization by decomposing woody debris and the recovery of tropical wet forest from hurricane damage. Oikos 72(3):314-322. https://doi.org/10.2307/3546116

\section{Submit your manuscript to a SpringerOpen ${ }^{\circ}$ journal and benefit from:}

- Convenient online submission

- Rigorous peer review

- Open access: articles freely available online

- High visibility within the field

- Retaining the copyright to your article

Submit your next manuscript at $\boldsymbol{\nabla}$ springeropen.com 